\title{
Pengaruh jus jambu biji dan jus apel hijau terhadap penurunan kadar kolesterol
}

\author{
Djunizar Djamaludin ${ }^{1 *}$, Meilisa Tabrani²
}

1Program Studi Ilmu Keperawatan Fakultas Kedokteran Universitas Malahayati. *Email: bluenavi01@gmail.com

2Puskesmas Satelit Kota Bandar Lampung

\author{
Abstract \\ Efficacy domestic apple (malus domestica) and guava fruit (psidium guajava I.) juices \\ in the management of blood cholesterol levels
}

Background: Hypertension is a chronic condition, which is blood pressure increases in the blood vessels. One of the causes of hypertension is a diet with high fat. High-fat levels occur precipitation of cholesterol. The methods to overcome hyper cholesterol in the blood by pharmacological and non-pharmacological. Method of nonpharmacological to reduce cholesterol levels with consuming guava and green apple juice.

Purpose: Known the efficacy domestic apple (Malus domestica) and guava fruit (Psidium guajava L.) juices in the management of blood cholesterol levels.

Method: The design of the research used in this study was a quasi-experiment used non-equivalent control group design. The samples were 16 samples. The sampling used a purposive sampling technique. The data analysis used Independent T-Test.

Results: The study showed that the average difference of cholesterol levels in the guava juice group was $17,25 \pm 17,019 \mathrm{mg} / \mathrm{dl}$. Meanwhile, the green apple juice group was $58,63 \pm 39,867 \mathrm{mg} / \mathrm{dl}$. The result of $\mathrm{t}$ value $=$ 2,700 and $p$ value $=0,017(p<0,05)$.

Conclusion: There was a difference effect of guava juice and green apple juice to cholesterol levels reduction. Suggestions of this study for hyper cholesterol patients to consume green apple juice as a non-pharmacological treatment.

Keywords: Cholesterol; Domestic Apple (Malus Domestica); Guava (Psidium guajava L.); Consumption; Juice.

Pendahuluan: Hipertensi adalah kondisi kronis dimana mengalami peningkatan tekanan darah pada dinding pembuluh darah. Salah satu penyebab hipertensi yaitu pola makan dengan kadar lemak tinggi. Kadar lemak tinggi menyebabkan terjadi endapan kolesterol. Cara mengatasi kelebihan kolesterol dalam darah dengan farmakologi dan nonfarmakologi. Cara nonfarmakologi menurunkan kadar kolesterol dengan mengonsumsi jus jambu biji dan jus apel hijau.

Tujuan: Diketahui perbedaan pengaruh jus jambu biji dan jus apel hijau terhadap penurunan kadar kolesterol.

Metode: Rancangan penelitian yang digunakan adalah quasi experiment dengan pendekatan non equivalent control group design. Sampel sebanyak 16 orang. Pengambilan sampel menggunakan teknik purposive sampling. Analisis data menggunakan uji Independent T-Test.

Hasil: Hasil penelitian menunjukkan perbedaan rata-rata kadar kolesterol pada kelompok jus jambu biji adalah $17,25 \pm 17,019 \mathrm{mg} / \mathrm{dl}$. Sedangkan, pada kelompok jus apel hijau adalah 58,63 $\pm 39,867 \mathrm{mg} / \mathrm{dl}$. Hasil nilai $\mathrm{t}=2,700$ dan $p$ value $=0,017(p<0,05)$.

Simpulan: Ada perbedaan pengaruh jus jambu biji dan jus apel hijau terhadap penurunan kadar kolesterol. Saran dari penelitian ini diharapkan penderita kolesterol mengonsumsi jus apel hijau sebagai pengobatan nonfarmakologi.

Kata Kunci: Kolesterol; Apel hijau; Jambu biji; Jus; Konsumsi

\section{PENDAHULUAN}

Berdasarkan data dari Riskesdas pada tahun 2013 menyimpulkan bahwa terjadi sebesar $25,8 \%$ prevalensi hipertensi di Indonesia dengan prevalensi paling tinggi terjadi di Bangka Belitung sebesar $30 \%$ dan yang paling rendah terjadi di Papua sebesar $16,8 \%$. Sementara itu, pada tahun 2016 data dari Survei Indikator Kesehatan Nasional menunjukkan bahwa penduduk usia $>18$ tahun mengalami peningkatan prevalensi 
hipertensi sebesar 32,4\% (Kementerian Kesehatan Republik Indonesia, 2018).

Didapatkan lima kabupaten/kota yang mengalami kejadian hipertensi dengan kategori tinggi, yaitu pertama pada Kabupaten Lampung Tengah sebanyak 261.027 orang, kedua pada Kabupaten Lampung Timur sebanyak 201.332 orang, ketiga pada Kabupaten Lampung Selatan sebanyak 181.325 orang, keempat pada Kota Bandar Lampung dengan jumlah 159.366 orang, dan kelima Kabupaten Tanggamus dengan jumlah 131.683 orang (Dinas Kesehatan Provinsi Lampung pada tahun 2017).

Salah satu penyebab orang terkena hipertensi yaitu karena pola makan yang buruk atau tidak sehat. Seseorang yang sering mengonsumsi makanan-makanan yang mempunyai kadar lemak tinggi akan berisiko terkena hipertensi. Kadar lemak tinggi menyebabkan terjadi endapan kolesterol pada dinding pembuluh darah atau disebut plak kolesterol. Pengendapan ion kalsium pada plak kolesterol menyebabkan plak yang tadinya lunak berubah menjadi keras dan kaku. Hal itu menyebabkan dinding pembuluh darah juga menjadi kaku dan tidak elastis. Selain itu adanya plak kolesterol yang mengeras menyebabkan dinding bagian dalam pembuluh darah menjadi sempit dan tidak licin, akibatnya untuk memompa darah melalui pembuluh darah itu jantung memerlukan tekanan yang lebih kuat dari biasanya. Oleh karena itu, tekanan darah akan meninggi. Kenaikan tekanan darah akibat pengerasan dan penyempitan pembuluh darah disebut hipertensi esensial (Moehji, 2017).

Persentase angka kejadian hiperkolesterolemia sebesar 9,3\% pada usia 25-34 tahun, sementara sebesar $15,5 \%$ pada usia $55-64$ tahun yang terjadi di Indonesia. Bersumber pada data dari penelitian MONICA I (Monitoring Trends and Determinants in Cardiovascular Diseases), persentase prevalensi hiperkolesterolemia pada perempuan yaitu sebesar $13,4 \%$ dan pada laki-laki yaitu sebesar $11,4 \%$. Data dari MONICA II diperoleh mengalami peningkatan pada perempuan menjadi sebesar $16,2 \%$ dan pada laki-laki menjadi sebesar $14 \%$. Hal ini menunjukkan bahwa kelompok paling banyak yang menderita masalah ini yaitu perempuan sebesar $14,5 \%$ atau hampir dua kali lipat dari kelompok laki-laki (Brata, 2015; Naue, Doda, \& Wungouw, 2016).

Adapun menyangkut pencegahannya, kolesterol tinggi dapat dicegah dengan gaya hidup sehat seperti menjaga berat badan, tidak merokok, makan asupan sehat, dan hindari stress. Sedangkan menyangkut cara penanganan untuk mengatasi kelebihan kolesterol dalam darah bisa dilakukan dengan cara farmakologi dan nonfarmakologi. Salah satu cara nonfarmakologi menurunkan kadar kolesterol dalam darah dengan mengonsumsi jus apel dan jus jambu biji. Jus apel sebagai solusi selain obat yang dapat dimanfaatkan untuk menurunkan kadar kolesterol berlebih pada tubuh dikarenakan kandungan vitamin, mineral, dan serat yang berguna menggeluarkan plak kolesterol yang melekat di pembuluh darah dan flavonoid pada apel bermanfaat untuk mengatasi kolesterol (Yovina, 2012; Antoni, \& Khoiri, 2013).

Buah lain yang berfungsi untuk menurunkan kolesterol yaitu jambu biji. Jambu biji kaya akan serat, khususnya pektin (serat larut air). Pektin memiliki berbagai manfaat antara lain menurunkan kolesterol dengan cara mengikat kolesterol dan asam empedu dalam tubuh serta membantu mengeluarkannya. Jambu biji juga mengandung kalium yang berfungsi meningkatkan keteraturan denyut jantung, menurunkan trigliserida darah dan kadar kolesterol total, serta menurunkan tekanan darah (Zukhri, Meinisa, \& Sulistyowati, 2018).

Puskesmas dengan kejadian hipertensi tertinggi terdapat di Puskesmas Satelit sebanyak 8.871 orang yang menderita hipertensi hanya 8.837 orang $(99,62 \%)$ mendapat pelayanan kesehatan hipertensi (Dinas Kesehatan Kota Bandar Lampung, 2018).

Berdasarkan masalah di atas, peneliti tertarik melakukan penelitian tentang "Perbedaan Pengaruh Jus Jambu Biji dan Jus Apel Hijau Terhadap Penurunan Kadar Kolesterol Pada Pasien Di Puskesmas Satelit Kota Bandar Lampung Tahun 2019".

\section{METODE PENELITIAN}

Jenis penelitian kuantitatif, Quasi Experiment dengan pendekatan Non Equivalent Control Group Design. Penelitian ini dilaksanakan di Puskesmas Satelit Bandar Lampung pada bulan April 2019. Populasi dalam penelitian ini sebanyak 263 orang dan sampel sebanyak 16 pasien. Teknik pengambilan sampel dalam penelitian ini dengan purposive sampling. Sampel dibagi menjadi 2 kelompok, masing-masing kelompok terdiri dari 8 pasien, kelompok pertama diberikan jus jambu biji dan kelompok kedua diberikan jus apel hijau,

Djunizar Djamaludin* Program Studi llmu Keperawatan Fakultas Kedokteran Universitas Malahayati.

*Email: bluenavi01@gmail.com

Meilisa Tabrani ${ }^{2}$ Puskesmas Satelit Kota Bandar Lampung 
masing-masing sebanyak $200 \mathrm{ml}$ selama 7 hari berturut-turut sebelum sarapan. Sampel diambil berdasarkan kriteria inklusi pada penelitian adalah pasien yang memiliki kolesterol > $200 \mathrm{mg} / \mathrm{dL}$, pasien laki-laki dan perempuan usia 45-65 tahun, dan bersedia menjadi objek penelitian. Analisis yang digunakan yaitu independent t-test untuk mengetahui ada tidaknya perbedaan pengaruh jus jambu biji dan jus apel hijau terhadap penurunan kadar kolesterol. Penelitian ini sudah lulus kelaikan etik dari Komisi Etik Penelitian Kesehatan Universitas Malahayati pada April 2019.

Langkah pertama melakukan pre test dengan mengkaji dan mengobservasi kolesterol pada pasien dengan cara mengukur kadar kolesterol dengan menggunakan Easy Touch Cholesterol Kit, kemudian dicatat kedalam lembar observasi pada hari pertama. Kemudian, melaksanaan intervensi dimana kelompok pertama diberikan jus jambu biji dan kelompok kedua diberikan jus apel hijau. Jus apel hijau dan jus jambu biji diberikan sebanyak $200 \mathrm{ml}$ per hari pada setiap kelompok, selama 7 hari berturut-turut. Selama penelitian berlangsung, peneliti dibantu oleh keluarga pasien untuk mengingatkan pasien agar mengonsumsi jus tersebut pada pagi hari sebelum sarapan.

Pada hari keempat peneliti melakukan observasi kolesterol pada pasien dengan cara mengukur kadar kolesterol dengan menggunakan Easy Touch Cholesterol Kit, kemudian dicatat kedalam lembar observasi. Hal ini bertujuan hanya untuk sebagai pemantauan kadar kolesterol. Kemudian melakukan post test dengan mengkaji dan mengobservasi kolesterol pada pasien dengan cara mengukur kadar kolesterol dengan menggunakan Easy Touch Cholesterol Kit pada hari terakhir setelah mengonsumsi jus apel hijau atau jus jambu biji, kemudian mencatatnya kedalam lembar observasi.

\section{HASIL}

Tabel 1. Karakteristik Demografi Responden N=16

\begin{tabular}{|c|c|c|c|c|c|}
\hline \multirow{2}{*}{ Demografi } & \multicolumn{3}{|c|}{ Kelompok Jus Jambu Biji } & \multicolumn{2}{|c|}{ Kelompok J } \\
\hline & n & $\%$ & $M \pm S D$ & $\mathbf{n}$ & $\%$ \\
\hline Usia (Tahun)(Rentang: 45-65) & & & $55.63 \pm 6.37$ & & \\
\hline \multicolumn{6}{|l|}{ Jenis Kelamin: } \\
\hline Laki-laki & 2 & 25 & & 3 & 37.5 \\
\hline Perempuan & 6 & 75 & & 5 & 62.5 \\
\hline \multicolumn{6}{|l|}{ Pekerjaan: } \\
\hline Pensiunan & 2 & 25 & & 0 & 0 \\
\hline PNS & 2 & 25 & & 1 & 12.5 \\
\hline Swasta & 0 & 0 & & 2 & 25 \\
\hline Pedagang & 1 & 12.5 & & 2 & 25 \\
\hline IRT & 3 & 37.5 & & 3 & 37.5 \\
\hline
\end{tabular}

Perlakuan:

- Pre test

- Post test

$8 \quad 246.38 \pm 20.35$

$229.13 \pm 28.09$

$240.89 \pm 26.54$

p-value

$M \pm S D$

$50.75 \pm 6.41$

${ }^{*} p<0,05$, paired t-test

Djunizar Djamaludin* Program Studi llmu Keperawatan Fakultas Kedokteran Universitas Malahayati.

*Email: bluenavio1@gmail.com

Meilisa Tabrani ${ }^{2}$ Puskesmas Satelit Kota Bandar Lampung 
Berdasarkan Tabel 1. distribusi frekuensi pasien berdasarkan usia pada rentang: 45-65 dimana pada kelompok pertama yang diberikan jus jambu biji dengan mean 55.63 dan standar deviasi 6.37 sebanyak 3 pasien $(37,5 \%)$ dan pada kelompok kedua yang diberikan jus apel hijau dengan mean 50.75 dan standar deviasi 6.41. Usia dapat memengaruhi kadar kolesterol total seseorang. Pada usia semakin tua kadar kolesterol totalnya relatif lebih tinggi daripada kadar kolesterol total pada usia muda, hal ini dikarenakan makin tua seseorang maka aktivitas reseptor LDL makin berkurang. Sel reseptor ini berfungsi sebagai hemostasis pengatur peredaran kolesterol dalam darah dan banyak terdapat dalam hati, kelenjar gonad, dan kelenjar adrenal. Apabila sel reseptor ini terganggu maka kolesterol akan meningkat dalam sirkulasi darah (Naue, Doda, \& Wungouw, 2016).

Berdasarkan jenis kelamin bahwa sebagian besar pasien berjenis kelamin perempuan yaitu masing-masing kelompok sebanyak 6 pasien (75\%) dan 5 pasien (62,5\%). Profil lipid menurut jenis kelamin menunjukan bahwa perempuan mempunyai kadar kolesterol total $\geq 240 \mathrm{mg} / \mathrm{dl}$, LDL kolesterol $\geq 160 \mathrm{mg} / \mathrm{dl}$ lebih besar dibanding lakilaki. Sedangkan, laki-laki mempunyai kadar HDL Kolesterol < $40 \mathrm{mg} / \mathrm{dl}$ lebih besar dibandingkan perempuan (Naue, Doda, \& Wungouw, 2016).

Berdasarkan pekerjaan terbanyak yaitu sebagian besar pasien bekerja sebagai IRT (lbu Rumah Tangga) sebanyak 3 pasien (37,5\%) pada masing-masing kelompok. Ibu rumah tangga rentan terhadap peningkatan kadar LDL dan peningkatan kolesterol total, dengan pola makan yang salah seperti makanan tinggi asupan lemak, kurang mengonsumsi sayuran dan buah juga akan memengaruhi kolesterol LDL dan kolesterol total dalam darah meningkat dan otomatis menurunkan kolesterol HDL. lbu rumah tangga yang mengonsumsi asupan lemak dan mengonsumsi tinggi karbohidrat ditemukan kadar HDL-nya rendah. Itu artinya, pembentukan kolesterol baik yang bertugas membawa lemak dari jaringan ke hati menjadi terganggu (Ardian, 2018).

Didapatkan hasil penelitian yang dilakukan dengan memberikan jus jambu biji dan jus apel hijau selama 7 hari berturut-turut, serta pengukuran kadar kolesterol sebelum dan sesudah perlakuan didapatkan data bahwa rata-rata kolesterol sebelum diberikan perlakuan pada kelompok jus jambu biji adalah sebesar 246,38 $\mathrm{mg} / \mathrm{dl}$, sedangkan rata-rata kolesterol sesudah perlakuan sebesar 229,13 mg/dl. Hal tersebut menunjukkan bahwa pemberian jus jambu biji dapat menurunkan kadar kolesterol. Sementara itu, rata-rata kolesterol sebelum diberikan perlakuan pada kelompok jus apel hijau adalah sebesar $240,88 \mathrm{mg} / \mathrm{dl}$, sedangkan rata-rata kolesterol sesudah perlakuan sebesar 182,25 mg/dl. Hal tersebut menunjukkan bahwa pemberian jus apel hijau dapat menurunkan kadar kolesterol.

Hasil uji analisis dengan menggunakan Uji Paired T-Test pada kelompok perlakuan yang diberikan jus jambu biji didapatkan $p$ value sebesar 0,024 dengan $p$ value $<0,05$. Hasil penelitian menunjukkan bahwa ada pengaruh pemberian jus jambu biji terhadap penurunan kadar kolesterol. Sedangkan, hasil uji analisis dengan menggunakan Uji Paired T-Test pada kelompok perlakuan yang diberikan jus apel hijau didapatkan $p$ value sebesar 0,004 dengan $p$ value $<0,05$. Hasil penelitian menunjukkan ada pengaruh pemberian jus apel hijau terhadap penurunan kadar kolesterol.

Hasil penelitian ini sesuai dengan penelitian Zukhri, Meinisa, \& Sulistyowati (2018) dengan judul "Perbedaan Pengaruh Jus Jambu Biji Dengan Jus Apel Hijau Terhadap Penurunan Kadar Kolesterol Darah". Rata-rata kadar kolesterol sebelum pemberian jus jambu biji sebesar 262,10 mg/dl, sedangkan rata-rata kadar kolesterol sesudah pemberian jus jambu biji sebesar 246,20 mg/dl. Sementara itu, rata-rata kadar kolesterol sebelum pemberian jus apel hijau sebesar $266,20 \mathrm{mg} / \mathrm{dl}$, sedangkan rata-rata kadar kolesterol sesudah pemberian jus apel hijau sebesar 246,50 mg/dl. 
Tabel 2. Perbedaan Pengaruh Jus Jambu Biji dan Jus Apel Hijau terhadap Penurunan Kadar Kolesterol

\begin{tabular}{cccccc}
\hline & Kelompok & Mean \pm SD & t & $95 \%$ Cl & $p-$ value \\
\cline { 2 - 6 } $\begin{array}{c}\text { Perbedaan Kadar } \\
\text { Kolesterol }\end{array}$ & Jus Jambu Biji & $17.25 \pm 17.02$ & & & \\
& Jus Apel Hijau & $58.63 \pm 39.87$ & & & \\
& & & & & \\
& & & & & \\
\end{tabular}

\section{${ }^{*} p<0,05$, independent $t$-test}

Berdasarkan Tabel 2. diketahui bahwa perbedaan rata-rata kadar kolesterol pada pasien yang diberikan jus jambu biji adalah $17,25 \mathrm{mg} / \mathrm{dl}$ dengan standar deviasi $17,019 \mathrm{mg} / \mathrm{dl}$, sedangkan pada pasien yang diberikan jus apel hijau perbedaan rata-rata kadar kolesterol dalam darah adalah 58,63 mg/dl dengan standar deviasi 39,867 $\mathrm{mg} / \mathrm{dl}$. Hasil nilai t hitung sebesar 2,700 > t tabel sebesar 2,120. Hasil uji statistik Independent $T$ Test didapatkan nilai $p$ value $=0,017(p<0,05)$, maka $\mathrm{Ha}$ diterima dan Ho ditolak. Hal ini menunjukkan bahwa ada perbedaan pengaruh yang signifikan antara jus jambu biji dan jus apel hijau terhadap penurunan kadar kolesterol, dimana jus apel hijau lebih efektif dibandingkan jus jambu biji.

\section{PEMBAHASAN}

Jambu biji berfungsi untuk menurunkan kadar kolesterol. Jambu biji memiliki kandungan zat gizinya yang tinggi, seperti vitamin $\mathrm{C}$, kalium, dan zat besi. Vitamin $C$ memiliki manfaat untuk menjaga dan memacu kesehatan pembuluh kapiler. Jambu biji juga kaya zat non gizi, seperti serat pangan, komponen karotenoid, dan polifenol (Astawan, 2006; Zukhri, Meinisa, \& Sulistyowati, 2018). Jambu biji per $100 \mathrm{~g}$ mengandung pektin sebanyak 5,4 gram dan kalium $417 \mathrm{mg}$ (United States Department of Agriculture, 2018). Hasil penelitian ini sesuai dengan teori dalam penelitian yang dilakukan oleh Zukhri, Meinisa, \& Sulistyowati (2018) menunjukkan bahwa jambu biji kaya akan serat, khususnya pektin (serat larut air). Pektin memiliki berbagai manfaat antara lain menurunkan kolesterol dengan cara mengikat kolesterol dan asam empedu dalam tubuh serta membantu mengeluarkannya. Jambu biji juga mengandung kalium yang berfungsi meningkatkan keteraturan denyut jantung, mengaktifkan kontraksi otot, mengatur pengiriman zat-zat gizi lainnya ke sel-sel tubuh, mengendalikan keseimbangan cairan pada jaringan dan sel tubuh, menurunkan trigliserida darah dan kadar kolesterol total, serta menurunkan tekanan darah.

Buah jambu biji bebas dari sodium dan asam lemak jenuh, rendah lemak, dan energi. Tetapi, tinggi akan serat pangan yang dapat meningkatkan ekskresi asam empedu dan kolesterol melalui feses sehingga mengurangi laju enterohepatik pada asam empedu. Rendahnya kadar asam empedu yang masuk ke hepar dan rendahnya absorbsi kolesterol dapat menurunkan kadar kolesterol di dalam hepar. Selanjutnya kolesterol diambil dari darah untuk menyintesis asam empedu, sehingga kolesterol dalam darah menurun (Dalimartha, 2014; Zukhri, Meinisa, \& Sulistyowati, 2018).

Serat dalam makanan memiliki hubungan dengan kadar kolesterol karena berfungsi untuk mengikat lemak yang terjadi di usus dan perut. Serat membentuk gelatin dan dalam proses pencernaan mengikat asam empedu dan kolesterol selanjutnya dikeluarkan melalui feses, sehingga kadar kolesterol yang masuk ke dalam darah menurun. Proses penurunan kadar kolesterol terkait dengan fungsi hati dalam memproduksi asam empedu. Serat larut air mengikat dikeluarkan melalui feses. Hal ini menyebabkan hati memproduksi lebih banyak asam empedu untuk mengganti asam empedu yang hilang. Pembentukan asam empedu memerlukan kolesterol, sehingga kolesterol akan terpakai dan tidak tertimbun di arteri dan menyebabkan kolesterol dalam darah menurun. Mekanisme lainnya yaitu penurunan absorpsi lemak dan kolesterol, penurunan laju serum insulin sehingga menurunkan rangsangan sintesis kolesterol dan lipoprotein, penghambatan sintesis kolesterol oleh asam lemak rantai pendek yang dihasilkan dari fermentasi serat larut di dalam kolon (Muliawati, Novianti, \& Hidayanti, 2014; Zukhri, Meinisa, \& Sulistyowati, 2018).

Selain itu, buah apel hijau juga dapat dimanfaatkan untuk menurunkan kadar kolesterol

\footnotetext{
Djunizar Djamaludin ${ }^{1 *}$ Program Studi llmu Keperawatan Fakultas Kedokteran Universitas Malahayati.

*Email: bluenavi01@gmail.com

Meilisa Tabrani ${ }^{2}$ Puskesmas Satelit Kota Bandar Lampung
} 
berlebihan pada tubuh dikarenakan kandungan vitamin, mineral, dan serat yang berguna menggeluarkan plak kolesterol yang melekat di pembuluh darah dan flavonoid pada apel bermanfaat untuk mengatasi kolesterol (Yovina, 2012; Antoni, \& Khoiri, 2013). Apel per $100 \mathrm{~g}$ mengandung flavonoid $407 \mathrm{mg}$ dan pektin sebanyak 2,4 gram (Cempaka, Santoso, \& Tanuwijaya, 2014). Hal ini sesuai dengan penelitian yang dilakukan oleh Darsini (2015) bahwa apel memiliki pektin yang dikenal sebagai antikolesterol karena dapat mengikat asam empedu yang merupakan hasil akhir metabolisme kolesterol, makin banyak asam empedu yang berikatan dengan pektin dan terbuang keseluruh tubuh makin banyak kolesterol yang di metabolisme, sehingga pada akhirnya kolesterol menurun jumlahnya. Karena itu, konsumsi apel secara teratur dapat menjaga keseimbangan gula darah, menurunkan kolesterol darah, dan juga menurunkan tekanan darah.Apel juga memiliki flavonoid yang merupakan antioksidan potensial pencegah pembentukan radikal bebas. Senyawa ini mampu mencegah perlengketan sel darah dan kerusakan HDL. Asupan makanan sumber flavonoid mengencerkan kembali darah pekat akibat penyumbatan pembuluh darah oleh kolesterol dan menjaga kadar normal HDL. Oleh karena itu, flavonoid menghambat terjadinya serangan penyakit jantung koroner dan stroke.

Apel Manalagi (Malus sylvestris Mill) adalah salah satu apel hijau yang dibudidayakan di Indonesia dan cukup familier bagi masyarakat. Kandungan apel manalagi yang diduga dapat menurunkan kadar kolesterol dalam darah yaitu pektin, flavonoid, niasin, dan vitamin C (Dalimartha, \& Adrian, 2013; Damayanti, 2016). Buah Apel Manalagi merupakan salah satu apel lokal dengan kandungan pektinnya sebesar 0.140.98\% (Abidah, et al., 2014; Nurman, Masrul, \& Sastri 2017).

Hasil penelitian ini sesuai dengan penelitian sebelumnya yang dilakukan oleh Zukhri, Meinisa, \& Sulistyowati (2018) yang membandingkan efek pemberian jus jambu biji dan jus apel hijau terhadap penurunan kolesterol pada 20 pasien dengan $p=0,001(p<0,05)$ yang berarti ada perbedaan bermakna antara jus jambu biji dan jus apel hijau dalam menurunkan kolesterol total. Hasil penelitiannya menunjukkan bahwa pemberian jus apel hijau lebih efektif menurunkan kadar kolesterol dibandingkan dengan jus jambu biji.
Berdasarkan uraian diatas peneliti berpendapat bahwa jus apel hijau berpengaruh terhadap penurunan kadar kolesterol pada pasien di Puskesmas Satelit. Hal ini sesuai dengan teori bahwa buah apel dapat membantu menjaga kadar kolesterol agar tetap normal karena kandungan pektin dan flavonoid yang terdapat di dalam buah apel.

\section{SIMPULAN}

Dari 16 pasien didapatkan hasil rata-rata kadar kolesterol kelompok sebelum dan sesudah diberikan jus jambu biji adalah 246,38 mg/dl dan $229,13 \mathrm{mg} / \mathrm{dl}$. Rata-rata kadar kolesterol kelompok sebelum dan sesudah diberikan jus apel hijau adalah 240,88 mg/dl dan 182,25 mg/dl. Perbedaan rata-rata kadar kolesterol pada pasien yang diberikan jus jambu biji adalah 17,25 mg/dl, sedangkan pada pasien yang diberikan jus apel hijau adalah 58,63 mg/dl. Hasil uji statistik Independent T-Test didapatkan nilai $p$ value $=$ $0,017(p<0,05)$ yang artinya ada perbedaan pengaruh yang signifikan antara jus jambu biji dan jus apel hijau terhadap penurunan kadar kolesterol pada pasien di Puskesmas Satelit, dimana jus apel hijau lebih efektif dibandingkan jus jambu biji.

\section{SARAN}

Perlu diadakan penyuluhan secara rutin tentang kolesterol dan pentingnya mengonsumsi jus jambu biji dan jus apel hijau, terutama jus apel hijau karena lebih efektif membantu menurunkan kadar kolesterol dalam darah. Sebagai bahan referensi dalam melakukan penelitian selanjutnya dan dapat mengkaji food recall untuk melihat jumlah konsumsi kolesterol pasien secara kuantitatif pada awal perlakuan dan akhir perlakuan. Sehingga dapat dihitung konsumsi kolesterol per hari. Sebaiknya penelitian ini dilakukan dalam waktu yang lebih lama (lebih dari 7 hari), dilakukan untuk sampel yang lebih banyak, dan perhatikan faktor-faktor yang memengaruhi kolesterol sehingga hasil penelitian dapat lebih baik.

\section{DAFTAR PUSTAKA}

Abidah, N., Widyaningsih, T. D., Nugraheni, N. I. P., Wijayanti, S. D., \& Maligan, J. M. (2013). Pengaruh margarin apel manalagi tersuplementasi minyak kacang tanah terhadap

Djunizar Djamaludin* Program Studi llmu Keperawatan Fakultas Kedokteran Universitas Malahayati.

*Email: bluenavio1@gmail.com

Meilisa Tabrani ${ }^{2}$ Puskesmas Satelit Kota Bandar Lampung 
kadar kolesterol tikus sprague dawley jantan [In Press Januari 2014]. Jurnal Pangan dan Agroindustri, 2(1), 18-27.

Antoni, R. Z., \& Khoiri, A. N. (2013). Pengaruh Konsumsi Jus Apel Terhadap Penurunan Kolesterol Darah Pada Penderita Hipertensi di Dusun Pojok Desa Curahmalang Kecamatan Sumobito Jombang. Jurnal Metabolisme Vol. 2 No. 3 Juli 2013, 2(3).

Ardian, J. (2018). Pengaruh asupan jus jambu biji merah (psidium guajaval) dan juspepaya (carica papaya I) terhadap kadar Idl (low density lipoprotein) dan kolesterol total pada ibu rumah tangga usia 40-70 tahun (Doctoral dissertation, Universitas Sebelas Maret).

Astawan, M. (2006). Vitamin C Terbaik dari Jambu Biji. Kompas. Cybermedia. Jakarta.

Brata, H. W. (2015). Hubungan Pola Makan, Obesitas, Keteraturan Berolahraga dan Kebiasaan Merokok Dengan Kejadian Hiperkolesterolemia. Universitas

Muhammadiyah Semarang. Diunduh tanggal, 25.

Cempaka, A. R., Santoso, S., \& Tanuwijaya, L. K. (2014). Pengaruh metode pengolahan (Juicing dan Blending) terhadap kandungan quercetin berbagai varietas apel lokal dan impor (Malus domestica). Indonesian Journal of Human Nutrition, 1(1), 14-22.

Dalimartha, S., \& Adrian, F. (2013). Fakta IImiah Buah Sayur. Penebar PLUS+.

Dalimartha, S., \& Dalimartha, F. A. (2014). Tumbuhan sakti atasi kolesterol. Penebar Swadaya Grup.

Damayanti, M. N., \& Ruhyana, R. (2016). Pengaruh pemberian apel manalagi terhadap kadar kolesterol penduduk dusun
Semarangan Sidokarto Godean Sleman Yogyakarta (Doctoral dissertation, Universitas' Aisyiyah Yogyakarta).

Darsini, M. (2017). Pengaruh konsumsi jus apel terhadap penurunan kolesterol darah pada penderita hipertensi. Jurnal Keperawatan dan Kebidanan, 7(1).

Dinas Kesehatan Kota Bandar Lampung. (2018). Capaian Indikator Standar Pelayanan Minimal (SPM). Bandar Lampung: Dinas Kesehatan Kota Bandar Lampung.

Dinas Kesehatan Provinsi Lampung. (2017). Data Estimasi Jumlah Penderita Hipertensi. Bandar Lampung: Dinas Kesehatan Provinsi Lampung

Kementerian Kesehatan Republik Indonesia. (2018). Hipertensi Membunuh Diam-Diam, Ketahui Tekanan Darah Anda. Jakarta: Kementerian Kesehatan RI. Diakses: www.depkes.go.id

Moehij, S. (2017). Dasar Dasar IImu Gizi 1. Jakarta: Pustaka Kemang.

Muliawati, D., Novianti, S., \& Hidayanti, L. Hubungan kebiasaan konsumsi serat dengan kadar kolesterol total pasien rawat jalan Rumah Sakit TMC Tasikmalaya 2014.

Naue, S. H., Doda, V., \& Wungouw, H. (2016). Hubungan kadar kolesterol total dengan tekanan darah pada guru di SMP 1 \& 2 Eben Haezar dan SMA Eben Haezar Manado. Jurnal e-Biomedik, 4(2).

Nurman, Z., Masrul, M., \& Sastri, S. (2018). Pengaruh Pektin Buah Apel (Malus Sylvestris Mill) Terhadap Kadar LDL Kolesterol pada Tikus Putih Jantan (Rattus Novergicus) Hiperkolesterolemia. Jurnal Kesehatan Andalas, 6(3), 679-684. 
United States Department of Agriculture. (2018). National Nutrient Database For Standard Reference Of Guavas. Amerika: Departemen Pertanian Amerika Serikat. Diakses: https://ndb.nal.usda.gov

Yovina, S. (2012). Kolesterol? Siapa Takut! Panduan Hidup Sehat Tanpa Kolesterol.
Zukhri, S., Meinisa, T. I., \& Sulistyowati, A. D. (2018). Perbedaan pengaruh jus jambu biji dengan jus apel hijau terhadap penurunan kadar kolesterol darah. Motorik Jurnal IImu Kesehatan, 13(27). 